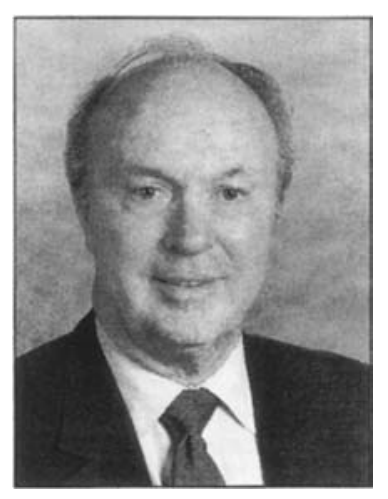

\author{
KENNETH R. FARRELL \\ Vice President \\ Agriculture and Natural Resources
}

\title{
Integrated resource management: new coalitions, familiar clientele
}

California's natural resources are under increasing stress. The symptoms are widely evident. In addition to the state's problems with impaired air and water quality, there is mounting evidence of damage to California's diverse biota-plants, animals, and microorganisms. The causes are complex, including invasions and introductions of exotic species, fires, a seven-year drought, and loss of habitat for wildlife due to urban development and agricultural, forestry, and grazing practices. Farmers, forest and grazing land managers, and industrial and urban developers are now confronted with growing public concern and an array of public policies and interest group activities aimed at protecting native species. What are the roles and obligations of the University in resolution of these issues?

For the long term, the University must elevate natural resource management to a higher priority in research and education. Natural resource management which will sustain both economic vitality and environmental quality involves a complex, highly interdependent process at both micro and macro, and private and public levels. As a publicly funded research and education institution, we should give greater emphasis to "integrated natural resources management" which takes into account the connections between California's genetically diverse ecological systems and its agricultural, economic and social systems.

The Division of Agriculture and Natural Resources is addressing resource management issues through statewide special programs and diverse research activities of faculty on the Berkeley, Davis and Riverside campuses. Individual researchers are investigating basic biology related to endangered and other species, developing more accurate biological sampling and analytic methods, using geographic information systems to map and better understand the natural landscape, restoring natural systems, and conducting economic and public policy analysis on a variety of natural resource issues.

Statewide programs that contribute to understanding of integrated resource management include: the Wildlands Resources Center, the Genetic Resources Conservation Program, the Sustainable Agriculture Research and Education Program, Sea Grant Extension and the Water Resources Center. Other DANR programs contributing to integrated resource management are the Salinity Drainage Task Force, the Integrated Hardwood Range Management Program, the Center for Pest Management, the Agricultural Issues Center, and the Natural Reserve System (NRS). Since NRS lands encompass many of the diverse habitats found in California, the Reserve System plays a unique role. It documents, investigates, and maintains the biological diversity found on reserve property. Reserves will serve as models for other areas in the state and as baseline sites for similar, less protected habitats.

In the future, even greater emphasis should be given to development of multi-disciplinary projects to address natural resource management. We must increase our efforts to engage the faculty's basic and applied research capacity in these problem- solving efforts and compete effectively for research funding from federal, state, and private foundation sources.

As educators, we must also increase the interdisciplinary capabilities of our students, across the bounds of physical, biological and social sciences, and into disciplines such as engineering and law. An important area needing more effort is secondary teacher training in biological and ecological concepts central to the understanding of natural resource conservation and management. We should also increase public understanding of how agricultural and urban systems can be managed to harmonize with natural ecosystems.

The University should provide statewide leadership in helping private interests and public agencies (local, state, and federal) design and implement strategies for integrated resource management of California's environment and economy. UC should be available as an objective, scientific leader in local and state land use and other natural resource planning efforts. It does not have regulatory authority over land use and natural resources, nor is it an advocate for particular policy solutions. However, the Division is well positioned to foster sound management of California's natural resources while enhancing the state's economic vitality by bringing to bear research and education resources in an integrated, cohesive manner. To accomplish this task we should foster and interact with new coalitions of familiar clientele: farmers, ranchers, environmentalists, timber interests, local, state and federal agencies, and urban dwellers.

Statewide efforts are now being organized to maintain and enhance the biological diversity and economic vitality of California through local groups devoted to sound ecosystem management. Recently, the Division joined 22 state, county, and federal agencies and the California Association of Resource Conservation Districts in signing a Memorandum of Understanding on

Biodiversity. The intent of the signatories is to foster solutions to California's resource problems identified at the local or regional level through a participatory process involving both public and private interests. University personnel are asked to serve as facilitators and scientific experts in these efforts. Our Cooperative Extension specialists and advisors and other Division staff are helping design solutions to resource problems in cooperation with a broad spectrum of local interests including agriculture.

Properly understood and implemented in a balanced manner, integrated resource management is consistent with the long-term interests of California agriculture. State agricultural leaders recognize that cooperation with natural resource interests and better mutual understanding of agricultural and natural resource systems are necessary to sustain California's agricultural productivity. The University of California can serve environmental, agricultural and other public interests by taking leadership in development of scientific integrated resource management strategies that protect the quality of California's natural resources and enhance economic vitality based on these resources. This is a challenge, and one the Division should welcome in the years ahead. 